\title{
Role of connective tissue growth factor in the pathogenesis of diabetic nephropathy
}

\author{
Nadia Abdel WAHAB, Natalia YEVDOKIMOVA ${ }^{1}$, Benjamin S. WESTON, Terry ROBERTS, Xin Jun LI, \\ Heike BRINKMAN and Roger M. MASON² \\ Cell and Molecular Biology Section, Division of Biomedical Sciences, Imperial College School of Medicine, Sir Alexander Fleming Building, Exhibition Road, \\ South Kensington, London, SW7 2AZ, U.K.
}

We characterized a rabbit polyclonal antibody raised against human recombinant connective tissue growth factor (CTGF). The antibody recognised a higher molecular mass form (approx. $56 \mathrm{kDa})$ of CTGF in mesangial cell lysates as well as the monomeric $(36-38 \mathrm{kDa})$ and lower molecular mass forms $(<30 \mathrm{kDa})$ reported previously. Immunohistochemistry detected CTGF protein in glomeruli of kidneys of non-obese diabetic mice 14 days after the onset of diabetes, and this was prominent by 70 days. CTGF protein is also present in glomeruli of human patients with diabetic nephropathy. No CTGF was detected in either normal murine or human glomeruli. Transient transfection of a transformed human mesangial cell line with a CTGF-V5 epitope fusion protein markedly increased fibronectin and plasminogen activator inhibitor-1 synthesis in cultures maintained in normal glucose (4 mM) conditions; a CTGF-antisense construct reduced the elevated synthesis of these proteins in high glucose $(30 \mathrm{mM})$ cultures. Culture of primary human mesangial cells for
14 days in high glucose, or in low glucose supplemented with recombinant CTGF or transforming growth factor $\beta 1$, markedly increased CTGF mRNA levels and fibronectin synthesis. However, whilst co-culture with a CTGF-antisense oligonucleotide reduced the CTGF mRNA pool by greater than $90 \%$ in high glucose, it only partially reduced fibronectin mRNA levels and synthesis. A chick anti-CTGF neutralizing antibody had a similar effect on fibronectin synthesis. Thus both CTGF and CTGFindependent pathways mediate increased fibronectin synthesis in high glucose. Nevertheless CTGF expression in diabetic kidneys is likely to be a key event in the development of glomerulosclerosis by affecting both matrix synthesis and, potentially through plasminogen activator inhibitor-1, its turnover.

Key words: fibronectin, fibrosis, non-obese diabetic mice, plasminogen activator inhibitor-1.

\section{INTRODUCTION}

Hyperglycaemia is implicated as the major factor initiating the development of diabetic nephropathy (DN) in humans and in animal models of diabetes mellitus [1]. DN is characterized by an accumulation of mesangial extracellular matrix, manifest as glomerulosclerosis, and by the development of tubulointerstitial fibrosis [2]. However, the molecular mechanisms driving these changes are less clear. Previously [3], using a subtraction hybridization technique, we identified upregulated expression of connective tissue growth factor (CTGF) in human mesangial cells (HMCs) exposed to high concentrations of glucose. This was confirmed by Murphy et al. [4]. CTGF is a cysteine-rich member of the CCN family of growth regulators, which includes Cyr61/Cef10, NOV and ELM-1 [5], and is a monomeric 36$38 \mathrm{kDa}$ secreted protein. However, other forms also exist such as a smaller 10-12 $\mathrm{kDa}$ product that retains biological activity [6], and $18 \mathrm{kDa}$ and $24 \mathrm{kDa}$ degradation products which have been found in human biological fluids [7]. The human CTGF gene has been mapped to chromosome $6 \mathrm{q} 23$. It has been reported to be transcriptionally activated by serum growth factors [8], transforming growth factor $\beta 1$ (TGF $\beta 1)[9,10]$, bone morphogenetic protein 2 [11], glucocorticoids such as dexamethasone [12], thrombin [13], lysophosphatidic acid and 5-hydroxytryptamine [14], high glucose and cyclic mechanical strain [15]. The regulation of CTGF gene expression appears to be through cis-acting elements in both the promoter [16] and the $3^{\prime}$-untranslated region [17].

The physiological function of CTGF has not yet been fully elucidated. However, it may be involved in the pathogenesis of fibrosis, possibly acting as a mediator of TGF $\beta 1[18,19]$. Increased expression of CTGF has been found in inflammatory bowel disease [20], skin lesions from scleroderma and systemic sclerosis [21,22], renal fibrosis [23,24], liver fibrosis [25], idiopathic pulmonary fibrosis and pulmonary sarcoidosis [26].

To assess the role of CTGF in the pathogenesis of DN, we first investigated its expression in the kidneys of non-obese diabetic (NOD) mice at various times after developing hyperglycaemia, and in non-hyperglycaemic control animals. We also examined CTGF levels in renal biopsy specimens from human DN patients. Secondly, we investigated whether transient overexpression or depleted expression of endogenous CTGF modulated the expression of fibronectin and plasminogen activator inhibitor-1 (PAI-1) in transformed HMC. Thirdly, we investigated whether

Abbreviations used: CRE, cAMP-response element; CTGF, connective tissue growth factor; rCTGF, recombinant CTGF; DN, diabetic nephropathy; FCS, foetal calf serum; GAPDH, glyceraldehyde-3-phosphate dehydrogenase; HMC, human mesangial cell; NOD, non-obese diabetic; PAI-1, plasminogen activator inhibitor-1; RT, reverse transcriptase; TGF $\beta 1$, transforming growth factor $\beta 1$; THMC, transformed HMC.

1 Present address: Molecular Immunology Department, Institute of Biochemistry, National Academy of Sciences of Ukraine, 9 Leontovicha str, 252030 Kiev, Ukraine.

2 To whom correspondence should be addressed (e-mail roger.mason@ic.ac.uk). 
CTGF is the only mediator for the effects of long-term exposure to high glucose or TGF $\beta 1$ on fibronectin expression in primary HMC cultures.

\section{MATERIALS AND METHODS}

Primary normal adult HMCs (CC-2259, lot 3F1510) from BioWhittaker (Wokingham, Berks., U.K.) were maintained in culture between passages $6-10$ as described previously [27]. Normal HMCs were transformed with simian virus 40 large T antigen following the Immortalex kit instructions (Novus Molecular, San Diego, CA, U.S.A.) and were cultured beyond crisis to obtain an immortalized line [transformed HMCs (THMCs)]. The THMCs were maintained in RPMI 1640 growth medium containing $4 \mathrm{mM}$ D-glucose as for primary cells, but the concentration of foetal calf serum (FCS) was reduced to $5 \%(\mathrm{v} / \mathrm{v})$, and insulin, transferrin, sodium and selenite were not added. This THMC line responded to high glucose conditions (see the Results section) and behaved very similarly in culture to another transformed line reported previously [28,29].

Recombinant human CTGF, rabbit anti-human CTGF antibody (pAb2), and chicken anti-human CTGF neutralizing antibody (pIgY3), together with their pre-immune sera, were kind gifts from FibroGen (South San Francisco, CA, U.S.A.). An anti-V5 epitope antibody was purchased from ClonTech. Recombinant TGF $\beta 1$ was from R \& D Systems (Abingdon, Oxfordshire, U.K.). Phosphothioate antisense (TGG GCA GAC GAA CG) and control oligonucleotides (ACC GAC CGA CGT GT) directed to CTGF were designed and manufactured by Biognostik GmbH (Göttingen, Germany), who own the intellectual property rights to the sequences.

Kidneys from NOD mice were kindly provided by Dr Masakazu Hattori (Joslin Diabetes Center, Boston, MA, U.S.A.). The animals had been screened for diabetes [30], the onset of diabetes being defined as the onset of hyperglycaemia. Control kidneys were from non-diabetic NOD mice that were transgenic for an E alpha transgene [31] and were a gift from Professor Anne Cooke (Department of Pathology, University of Cambridge, U.K.). Renal biopsies from three human DN patients were investigated using tissue surplus to requirements for diagnostic histology. Only biopsies for which a diagnosis of diabetic glomerulosclerosis had been confirmed by a renal pathologist using light and electron microscopy were used.

\section{RNA extraction and reverse transcriptase (RT)-PCR analysis}

Total RNA was extracted from $6 \times 10^{6}$ mesangial cells using the RNAzol B method [AMS Biotechnology (Europe), Abingdon, Oxfordshire, U.K.]. RNA was dissolved in diethyl pyrocarbonate-distilled water, quantified and stored at $-70^{\circ} \mathrm{C}$ until use. Equal amounts of total RNA $(2 \mu \mathrm{g})$ from each sample were reverse transcribed into cDNAs using SuperScript II RNase $\mathrm{H}^{+}$reverse transcriptase (Gibco BRL, Paisley, Renfrewshire, Scotland, U.K.) and random primers. Equal amounts $(0.5 \mu \mathrm{l})$ of the reverse transcription reaction $(20 \mu \mathrm{l})$ were subjected to PCR amplification in a $100 \mu \mathrm{l}$ volume containing $10 \mu \mathrm{l}$ of $10 \times$ PCR buffer, $16 \mu \mathrm{l}$ of dNTPs (1.25 mM each), $2 \mathrm{mM}$ $\mathrm{MgCl}_{2}, 0.5 \mu \mathrm{M}$ of each specific primer and 1.25 units of Amplitaq DNA polymerase (Gibco BRL). Amplification was started with 5 min of denaturation at $94^{\circ} \mathrm{C}$ followed by 27 PCR cycles. Each cycle consisted of $60 \mathrm{~s}$ at $94{ }^{\circ} \mathrm{C}, 60 \mathrm{~s}$ at $55^{\circ} \mathrm{C}$ and $60 \mathrm{~s}$ at $72{ }^{\circ} \mathrm{C}$. The final extension was for $10 \mathrm{~min}$ at $72{ }^{\circ} \mathrm{C}$. We co-amplified the housekeeping gene glyceraldehyde-3-phosphate dehydrogenase (GAPDH) to allow semi-quantificative comparison of PCR products and to confirm equivalent loading of RNAs. The amount of reverse transcription reaction used for the amplification $(0.5 \mu \mathrm{l})$ was selected as being non-saturating for the PCR product of all genes under investigation after 27 cycles of amplification. The sequences of primers were designed from the published sequences of the human genes and are listed in Table 1. After amplification, $10 \mu \mathrm{l}$ of each PCR reaction product was electrophoresed through a $1.2 \%(\mathrm{w} / \mathrm{v})$ agarose gel containing ethidium bromide $(0.5 \mu \mathrm{g} / \mathrm{ml})$. Gels were scanned using an Epson GT-8000 scanner and Adobe PhotoShop software.

\section{Cloning and sequence analysis}

A 1054 bp PCR fragment containing the whole coding region of the CTGF gene as well as $6 \mathrm{bp}$ upstream from the start codon was amplified by RT-PCR (Table 1) and cloned into the pcDNA3.1/V5-His TOPO vector (Invitrogen, Groningen, The Netherlands) in the sense orientation, or into the pTracer-CMV2 vector (Invitrogen) in the antisense orientation.

\section{Transient transfection}

THMCs were grown under $4 \mathrm{mM}$ D-glucose conditions. CTGFV5 constructs $(30 \mu \mathrm{g})$ or CTGF-antisense constructs $(30 \mu \mathrm{g})$ were transfected into $5 \times 10^{6}$ THMCs in $0.8 \mathrm{ml}$ of the optimized electroporation buffer, Optimix (EquiBio, Kent, U.K.). For controls, cells were transfected with the vectors without inserts (mock transfections). The protocol was modified slightly from that described previously [28]. Briefly, the cells and plasmid DNA were incubated at room temperature for $3 \mathrm{~min}$ prior to electroporation at $260 \mathrm{~V}, 1050 \mu \mathrm{F}$, using an Easyject Optima Electroporation Unit (Floegen, Staffordshire, U.K.). Immediately after the pulse the cell suspension was transferred to a T75 culture flask containing pre-warmed RPMI 1640 medium with $10 \%$ FCS. Transfection efficiency under these conditions was $>50 \%$. After overnight incubation at $37{ }^{\circ} \mathrm{C}$ in $5 \% \mathrm{CO}_{2}$, cultures

Table 1 Primer sequences for amplifying various transcripts

Abbreviation: ORF, open reading frame.

\begin{tabular}{|c|c|c|c|c|}
\hline \multirow[b]{2}{*}{ Transcript } & \multirow[b]{2}{*}{ Length of transcript (bp) } & \multicolumn{2}{|l|}{ Primers } & \multirow[b]{2}{*}{ Gene accession number } \\
\hline & & Sense & Antisense & \\
\hline Complete ORF of CTGF & 1029 & 5'-GCCAACCATGACCGCCGCCAG-3' & 5'-TGCCATGTCTCCGTACATCTTCCTG-3' & XM004525 \\
\hline CTGF & 477 & 5'-AACTATGATTAGAGCCAACTGCCTG-3' & 5'-TCATGCCATGTCTCCGTACATCTTC-3' & XM004525 \\
\hline Fibronectin & 639 & 5'-CGAAATCACAGCCAGTAG-3' & 5'-ATCACATCCACACGGTAG-3' & X02761 \\
\hline PAl-1 & 396 & 5'-GTATCTCAGGAAGTCCAGCC-3' & 5'-TCTAAGGTAGTTGAATCCGAGC-3' & M16006 \\
\hline GAPDH & 452 & 5'-ACCACAGTCCATGCCATCAC-3' & 5'-TCCACCACCCTGTTGCTGTA-3' & XM009352 \\
\hline
\end{tabular}


were washed three times with PBS and serum free medium was added. Cells and media were collected after a further $48 \mathrm{~h}$ incubation. Secreted recombinant CTGF (rCTGF) was purified from the medium using a Talon metal-affinity resin (ClonTech) or with a heparin affinity column (Sigma-Aldrich, Poole, Dorset, U.K.) according to the manufacturer's instructions.

\section{Western blotting}

Conditioned media were centrifuged $\left(500 \mathrm{~g}, 5 \mathrm{~min}, 4{ }^{\circ} \mathrm{C}\right)$ to remove any particulate matter before addition of ammonium sulphate (final concentration $20 \% \mathrm{w} / \mathrm{v}$ ). After incubating overnight at $4{ }^{\circ} \mathrm{C}$, samples were centrifuged $\left(14000 \mathrm{~g}, 15 \mathrm{~min}, 4^{\circ} \mathrm{C}\right)$ and the pellet solubilized in reducing SDS/PAGE loading buffer containing a cocktail of protease inhibitors (1 mM EDTA, $1 \mathrm{mM}$ EGTA, $0.2 \mathrm{mM}$ tosyl-lysylchloromethane ('TLCK'), $1 \mathrm{mM}$ $N$-ethylmaleimide, $\quad 0.1 \mathrm{mM}$ tosylphenylalanylchloromethane ('TPCK'), and $2 \mathrm{mM}$ PMSF; Sigma). Samples were boiled for 5 min and resolved on $4-12 \%$ gradient gels by SDS/PAGE. Proteins were transferred on to a PVDF membrane filter (Immobilin-P, Millipore) using a BioRad transfer apparatus. Immunodetection was performed essentially as described by Towbin et al. [32]. Bound antibodies were visualized using the enhanced chemiluminescence reagent Luminol (Autogen Bioclear, Calne, Wiltshire, U.K.). Prestained molecular-mass standards (Amersham International) were used to monitor protein migration.

\section{ELISA}

Conditioned media collected from cell cultures were diluted $1: 15$ with $0.05 \mathrm{M}$ sodium carbonate, $0.05 \mathrm{M}$ sodium bicarbonate, pH 9.6 (coating buffer), and $100 \mu \mathrm{l}$ of each sample was added to the wells of a NUNC microtitre plate (Gibco BRL) in triplicate. Protein was allowed to adsorb passively overnight at $4{ }^{\circ} \mathrm{C}$. Plates were washed three times with PBS $/ 0.05 \%$ (v/v) Tween 20 and blocked with $150 \mu \mathrm{l} \mathrm{PBS} /$ Tween 20 containing $0.5 \%(\mathrm{w} / \mathrm{v})$ casein (from bovine milk) for $2 \mathrm{~h}$ at $37^{\circ} \mathrm{C}$. After three further washes with PBS/Tween 20, $100 \mu 1$ (1:3000 dilution) of antihuman fibronectin antibody (Sigma) was added to each well and incubated for $1.5 \mathrm{~h}$ at $37^{\circ} \mathrm{C}$. Plates were washed once more and $100 \mu \mathrm{l}$ of goat anti-rabbit IgG conjugated to horseradish peroxidase (1:3000 dilution; Sigma) was added to each well for $1.5 \mathrm{~h}$ at $37^{\circ} \mathrm{C}$. A final wash was followed by development using the colorimetric reagent 2,2'-azinobis-(3-ethylbenzothiazoline-6sulphonic acid) (100 $\mu \mathrm{l}$ ) (Sigma). This was dissolved in $100 \mathrm{mM}$ citric acid and $100 \mathrm{mM} \mathrm{Na}_{2} \mathrm{HPO}_{4}, \mathrm{pH} 4.1$, to a final concentration of $0.4 \mathrm{mg} / \mathrm{ml}$, with the addition of $60 \mu \mathrm{l}$ of $\mathrm{H}_{2} \mathrm{O}_{2}(30 \%)$ per $25 \mathrm{ml}$ buffer immediately prior to use. Plates were read at $A_{405}$ in a Titertek Multiskan plate reader (MCC/340). Serial dilutions of standard fibronectin (Gibco BRL) were included on each plate to generate a standard curve. Each assay was repeated three times.

\section{Immunohistochemistry}

Kidneys were snap-frozen and sectioned in a cryostat at $8 \mu \mathrm{m}$. After fixation in acetone for $10 \mathrm{~min}$, sections were washed in PBS $/ 0.05 \%$ Tween 20 and pre-incubated in a malate buffer (100 mM maleic acid and $150 \mathrm{mM} \mathrm{NaCl}$,), pH 7.5, containing $2 \%$ blocking reagent (Roche Diagnostics, Lewes, East Sussex, U.K.) and $20 \%$ heat-inactivated FCS for $90 \mathrm{~min}$. Sections were then incubated with the primary rabbit anti-CTGF antibody (1: 300 dilution) overnight at $4{ }^{\circ} \mathrm{C}$, after which immunoreaction was detected with FITC-conjugated goat anti-rabbit antibody (1:200 dilution; Sigma). For controls, the anti-CTGF antibody was absorbed with rCTGF (1:3 mol. ratio) prior to incubation with the section. Coverslips were mounted on glass slides with antifade mounting media (Vector Laboratories, Peterborough, U.K.) and the sections examined with an Olympus AX70 fluorescence microscope.

\section{Quantitative analysis and statistics}

Western blots and photographs of DNA gels were scanned with an Epson GT-8000 scanner into Adobe PhotoShop software; the pixel intensity for each band (average pixel intensity multiplied by area) was analysed with the Image software (National Institutes of Health Shareware). Peak areas were measured in arbitrary units. To minimize error either in the scanning procedure or due to variation in band width and thickness, the procedure was repeated three times and the mean value was used. Results for each group of data are given as mean \pm S.E.M. Differences between means were tested with Student's unpaired $t$-test; $P<0.05$ was accepted as significant.

\section{RESULTS}

\section{Expression of a recombinant CTGF-fusion protein and characterization of the anti-CTGF antibody}

The full coding sequence of CTGF was cloned into the pcDNA3.1/V5-His TOPO vector and transfected into THMCs. The expressed CTGF-fusion protein contained the V5 epitope which provided an alternative means of immunodetection. The fusion protein was recovered from the medium of transfected cells by heparin-bead affinity purification and examined by SDS/PAGE and Western blotting with anti-V5 antibody (Figure 1A, media/CTGF-V5), or with anti-CTGF antibody (Figure 1B, media/CTGF-V5), or with anti-CTGF antibody which had been pre-absorbed with rCTGF (Figure 1C, media/CTGF-V5). Media from mock-transfected cells were treated in the same way as for transfected cells (Figures 1A-1C, media/mock). Western blotting of affinity-purified fractions with anti-V5 antibody revealed a doublet band of $42-44 \mathrm{kDa}$, the anticipated size for the fusion protein (Figure 1A, media/CTGFV5). A minor band (approx. $26 \mathrm{kDa}$ ) was also detected and must be a C-terminal product of proteolytic cleavage of the fusion protein (Figure 1A, media/CTGF-V5). The anti-CTGF antibody (pAb2) also detected a large doublet band of approx. $42-44 \mathrm{kDa}$, together with an additional $36-38 \mathrm{kDa}$ band, the latter being the anticipated size for endogenous CTGF (Figure 1B, media/CTGF-V5). Neither band is detected if the anti-CTGF antibody is first absorbed with rCTGF (Figure 1C, media/CTGF-V5). CTGF-V5 recovered from the culture media by metal-affinity using Talon resin gave the same result when examined by electrophoresis and Western blotting (results not shown).

We conclude that the $42-44 \mathrm{kDa}$ component in the medium is due to secreted CTGF-V5 fusion protein since (i) it is the correct size, (ii) it was detected with both anti-V5 and anti-CTGF antibodies in heparin-affinity fractions (Figures $1 \mathrm{~A}$ and 1B, media/CTGF-V5) and in Talon-affinity fractions from transfected cells, but not in fractions from mock-transfected cells (Figures 1A and 1B, media/mock), and (iii) it was not detected with pre-absorbed anti-CTGF antibody. Similarly the $36-38 \mathrm{kDa}$ band is attributed to endogenous CTGF on the basis of (i) molecular mass, (ii) detection with anti-CTGF antibody in heparin-affinity fractions from medium of either transfected or mock-transfected cells (Figure 1B, media/mock and media/ CTGF-V5), but not with anti-V5 antibody (Figure 1A, media/mock and media/CTGF-V5), (iii) detection with antiCTGF antibody in these fractions is abolished by pre-absorbing 


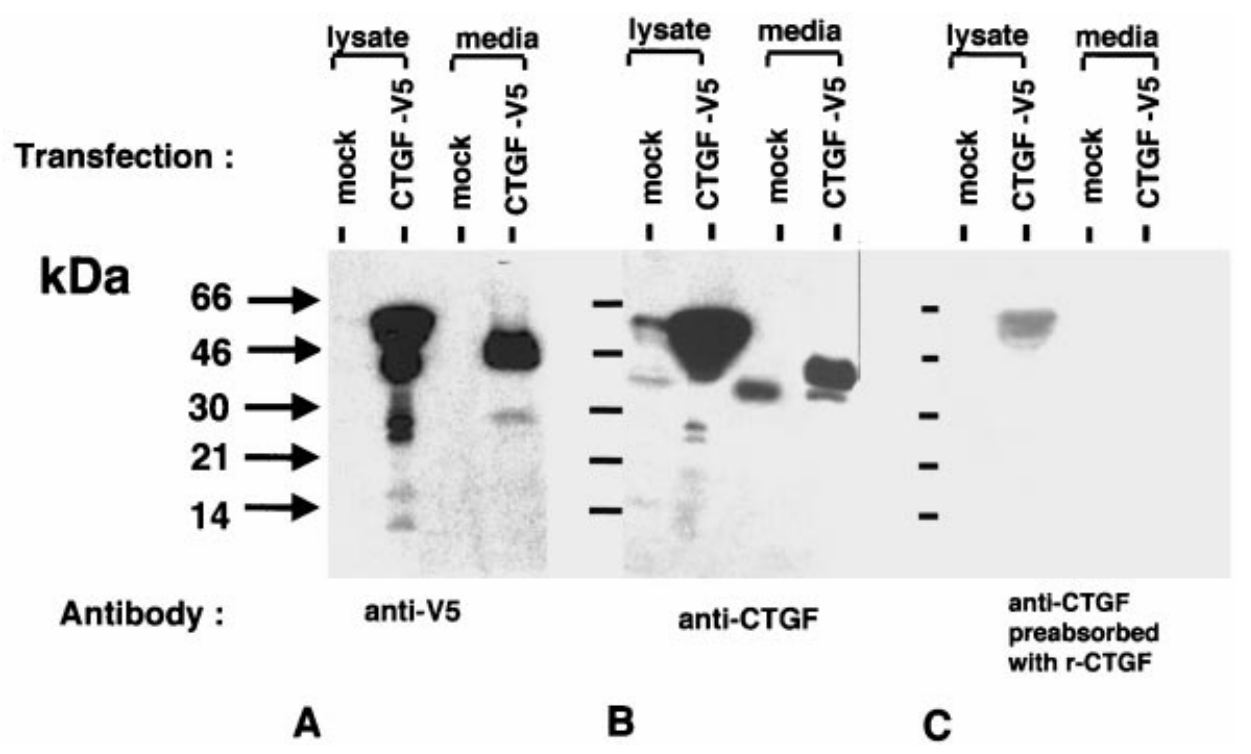

Figure 1 Expression of recombinant CTGF in THMC cultures

THMCS were transfected with a CTGF-V5 construct or were mock transfected, as described in the Materials and methods section. After $48 \mathrm{~h}$ culture in serum-free conditions, the cells were lysed in SDS/PAGE loading buffer, and secreted CTGF was purified from the medium using heparin-affinity beads. Samples of equal volume were resolved by SDS/PAGE (4-12\% gel) and Western blotted with either anti-V5 antibody (A), or rabbit anti-(human-CTGF) antibody (B), or with rabbit anti-CTGF antibody pre-absorbed with rCTGF (C). (A-C) First lane, cell lysate from mock-transfected cells; second lane, cell lysate from CTGF-V5-transfected cells; third lane, heparin-affinity purified fraction from culture medium of mock-transfected cells; fourth lane, heparin-purified CTGF fraction from culture medium of CTGF-V5-transfected cells.

the antibody with rCTGF (Figure 1C, media/mock and media/ CTGF-V5), (iv) the band is not detected in fractions purified from the medium by Talon-affinity chromatography (results not shown).

Western blotting of the cell lysate of THMCs transfected with pcDNA 3.1/V5-His using anti-V5 antibody (Figure 1A, lysate/CTGF-V5) or anti-CTGF antibody (Figure 1B, lysate/ CTGF-V5) indicates that the recombinant $42-44 \mathrm{kDa}$ CTGFfusion protein is also present intracellularly. As expected, it was not detected in mock-transfected cells (Figures 1A and 1B, lysate/mock). In addition both antibodies detected bands of higher (approx. $56 \mathrm{kDa}$ ) and lower (26 kDa and less) molecular mass in the lysate of transfected cells (Figures $1 \mathrm{~A}$ and $1 \mathrm{~B}$, lysate/CTGF-V5). Immunodetection of these bands is either abolished or markedly reduced by prior absorption of the antiCTGF antibody with rCTGF from Fibrogen (Figure 1C, lysate/CTGF-V5), indicating that they are derived from the CTGF-fusion protein and are not non-specific. The lower molecular mass bands are likely to be proteolytic cleavage products, whereas the prominent $56 \mathrm{kDa}$ band may be a dimer of the fusion protein and a cleavage product or of cleavage products alone. The $56 \mathrm{kDa}$ band cannot be due to cross reaction with another growth factor of the $\mathrm{CCN}$ family to which CTGF belongs since it was detected by anti-V5 antibody, as well as by anti-CTGF antibody. Interestingly, endogenous 36-38 kDa CTGF was also detected in the lysate of mocktransfected cells (Figure 1B, lysate/mock), together with the $56 \mathrm{kDa}$ band, indicating that the latter is formed in physiological conditions and is not an artifact of expressing the CTGF-V5 fusion protein.

CTGF protein $(36-38 \mathrm{kDa})$ was also detected in the medium of primary HMC cultures, and together with the $26 \mathrm{kDa}$ and $56 \mathrm{kDa}$ product, in lysates of these cells (results not shown). Immunodetection of all these bands was again competed out by
Table 2 Onset and duration of diabetes in NOD mice

The age of the non-diabetic control mice was 142 days.

\begin{tabular}{lll}
\hline Mouse & $\begin{array}{l}\text { Age of onset of } \\
\text { diabetes (days) }\end{array}$ & $\begin{array}{l}\text { Duration of } \\
\text { diabetes (days) }\end{array}$ \\
\hline 1 & 119 & 14 \\
2 & 158 & 21 \\
3 & 177 & 42 \\
4 & 163 & 56 \\
5 & 153 & 70 \\
6 & 197 & 70
\end{tabular}

prior absorption of anti-CTGF antibody with rCTGF. Thus these bands are formed in primary as well as in transformed HMC cultures.

\section{CTGF expression in renal cortex of NOD mice following onset of hyperglycaemia}

Sections of renal cortex from six NOD mice with different durations of diabetes (Table 2) and from control non-diabetic mice were immunostained with the rabbit anti-CTGF antibody. There was virtually no CTGF immunostaining in the glomeruli of control mice (Figure 2A), a finding which agrees well with the negligible levels of CTGF mRNA detected in the glomeruli of 5month-old non-diabetic littermate control mice [15] and with the absence of CTGF transcripts in normal adult rat glomeruli [4]. Tubular epithelial cells showed some immunofluorescence, but this occurred with secondary antibody alone and was therefore non-specific. The onset of hyperglycaemia in NOD mice occurred 

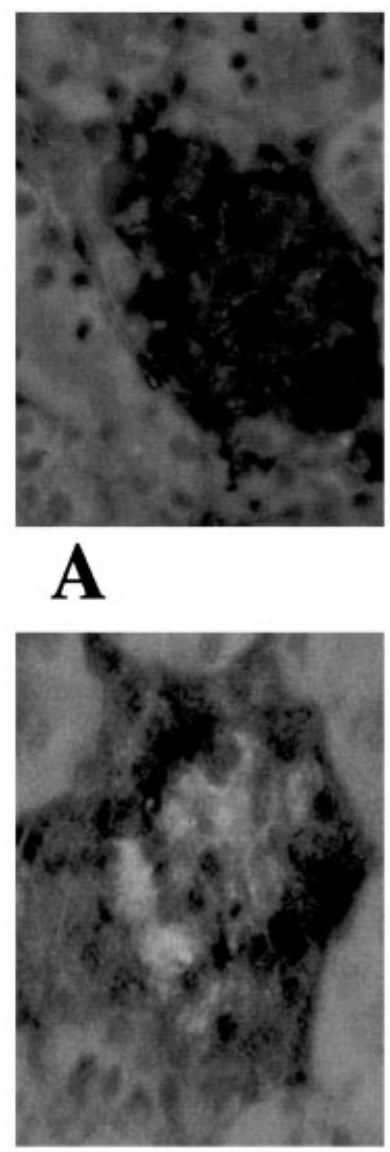

D

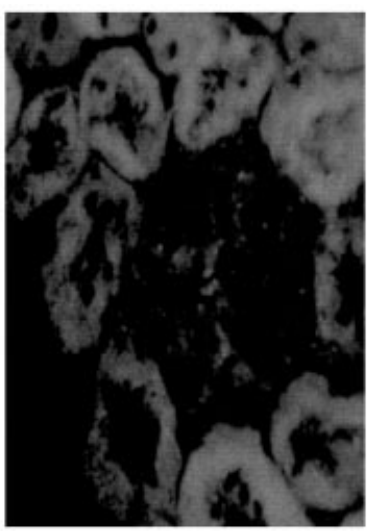

B

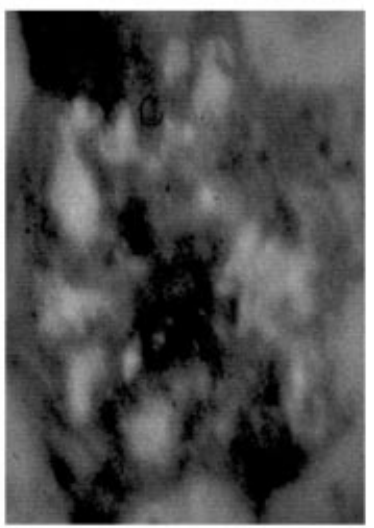

$\mathbf{E}$

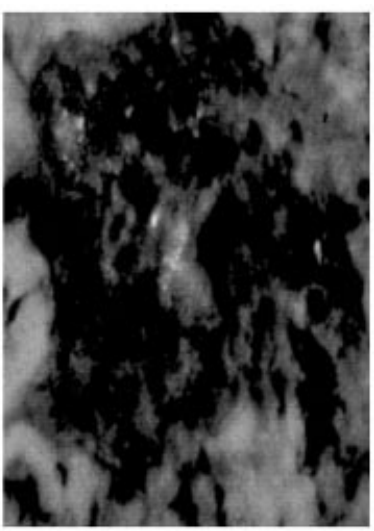

C

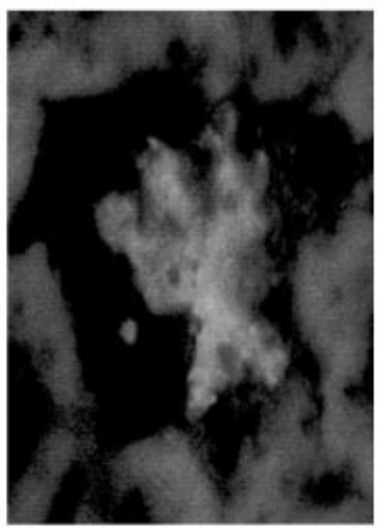

$\mathbf{F}$

\section{Figure 2 Expression of CTGF in glomeruli of NOD mice}

Frozen sections of renal cortex were tested for CTGF expression by immunohistochemistry as described in the text. (A) Glomerulus of control non-diabetic mouse aged 142 days. (B-F) Glomeruli during diabetes of duration 14 days (B), 21 days (C), 42 days (D), 56 days (E), and 70 days (F) in NOD mice. Details of age of onset of diabetes in NOD mice are given in Table 2. Magnification, $\times 143$.

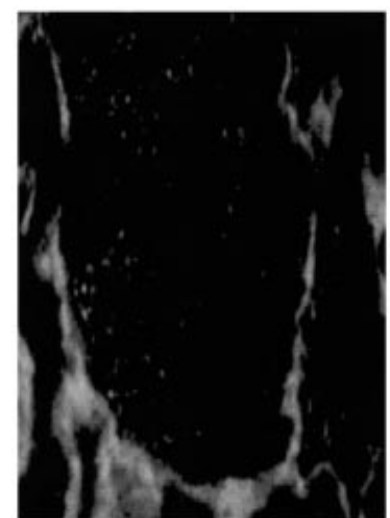

A

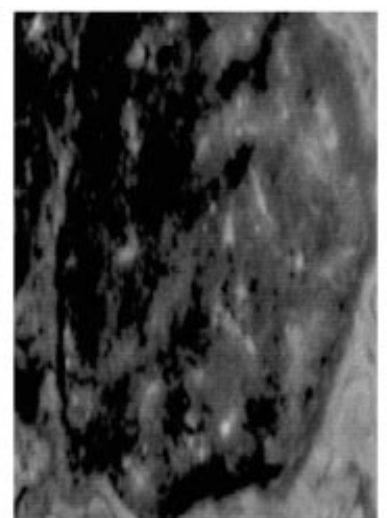

B

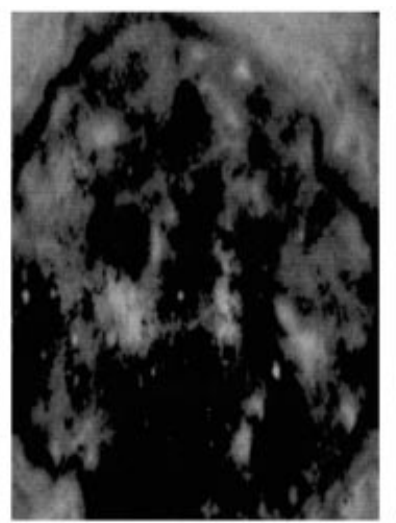

C

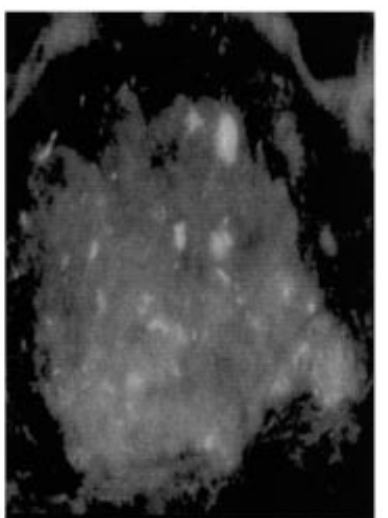

D

\section{Figure 3 Expression of CTGF in human glomeruli in DN}

Immunohistochemical detection of CTGF in glomeruli of frozen sections of normal human kidney (A), and of renal biopsies from diabetic patients aged 70 years with early diabetic glomerulosclerosis (B), aged 62 years with diffuse diabetic glomerulosclerosis (C), and aged 71 years with diffuse diabetic glomerulosclerosis (D). Disease classifications were provided by a renal pathologist and were based on wax sections of the same biopsies (results not shown). Magnification, $\times 143$. 


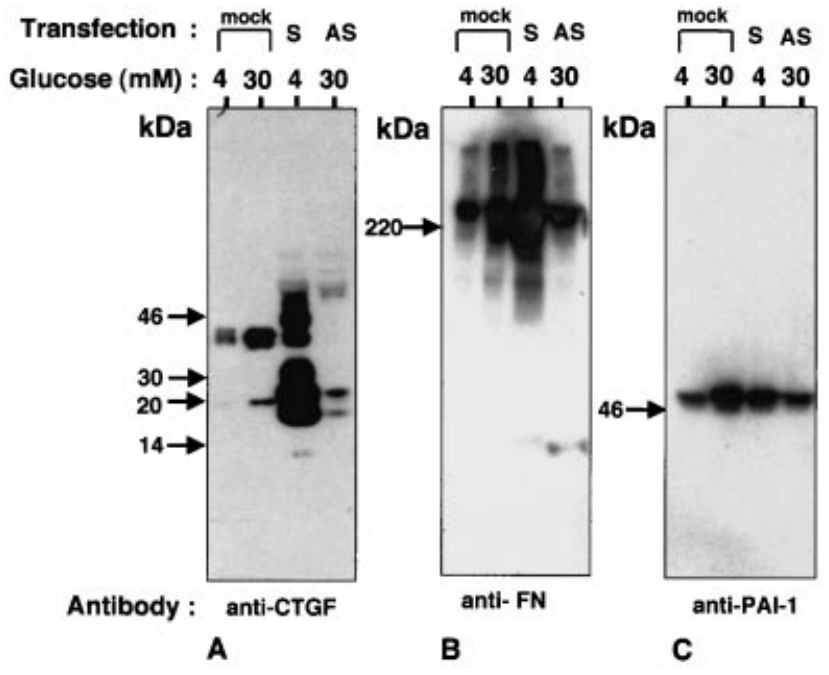

Figure 4 Effect of endogenous CTGF on the expression of fibronectin and PAI-1 in transiently transfected THMC cultures

Equal numbers of cells were either mock transfected (mock) and maintained under $4 \mathrm{mM}$ or $30 \mathrm{mM}$ D-glucose conditions, or were transfected with the CTGF-V5 construct and maintained under $4 \mathrm{mM}$ D-glucose conditions (S), or with the CTGF-antisense construct and maintained under $30 \mathrm{mM}$ D-glucose conditions (AS). Serum-free media were collected after $48 \mathrm{~h}$, precipitated and suspended in equal volumes of sample loading buffer of which one third of the volume was electrophoresed and immunoblotted with anti-CTGF (A), anti-fibronectin (FN) (B) or anti-(PAI-1) (C) antibodies. Results shown are typical of three separate experiments.

between 119-197 days of age in the animals investigated and kidneys were examined 14-70 days after the onset (Table 2). Glomerular CTGF immunostaining was just detectable at the early times after onset of hyperglycaemia (Figure 2B). However, glomerular expression of CTGF increases markedly with the duration of diabetes (Figures 2D-2F). NOD mice develop glomerulosclerosis with advancing diabetes [33], and the pattern of prominent CTGF immunostaining seen in the older animals is suggestive of enhanced expression in mesangial areas.

\section{CTGF expression in renal biopsy specimens of human DN patients}

No CTGF immunostaining was observed in the glomeruli of normal human kidney. As with the murine kidney sections, background immunofluorescence occurred in tubular epithelial cells and was due to the secondary antibody. Positive CTGF immunostaining was detected in the glomeruli of three human DN patients (Figure 3). As in the NOD mice, the pattern of staining suggests prominent mesangial expression.

\section{Transient overexpression of CTGF in HMCs and its effect on fibronectin and PAI-1 synthesis}

Previous studies have established that exposure of human and rat mesangial cells to high glucose conditions for 2-21 days increases CTGF mRNA levels $[3,4,15]$, and that the addition of exogenous rCTGF to cultures stimulates the synthesis of fibronectin and collagen I [15]. To investigate whether transient overexpression of endogenous CTGF could modulate fibronectin synthesis in human mesangial cells in normal glucose conditions $(4 \mathrm{mM})$, we transfected a mesangial cell line with the CTGF-V5 construct and measured synthesis over the following $48 \mathrm{~h}$. To examine the role of endogenous CTGF in modulating fibronectin synthesis during short-term exposure of HMCs to high glucose $(48 \mathrm{~h}$, $30 \mathrm{mM}$ ), we transfected cell line cultures with a CTGF-antisense construct to deplete mRNA levels of the growth factor. Control cultures were mock-transfected with empty vector. PAI-1 synthesis was also measured, in addition to fibronectin. After transfection $(4 \mathrm{~h})$, cells were washed and transferred to either serum-free medium supplemented with $4 \mathrm{mM}$ D-glucose (CTGFsense transfects and controls) or with $30 \mathrm{mM}$ D-glucose (CTGF-antisense transfects and controls). After a further $48 \mathrm{~h}$, conditioned media were analysed for fibronectin and PAI-1 by SDS/PAGE and Western blotting, whereas the cells were harvested for RNA extraction and mRNA analysis by RT-PCR.

High glucose conditions upregulated the expression level of CTGF, fibronectin and PAI-1 (Figures 4A-4C, mock/30) in

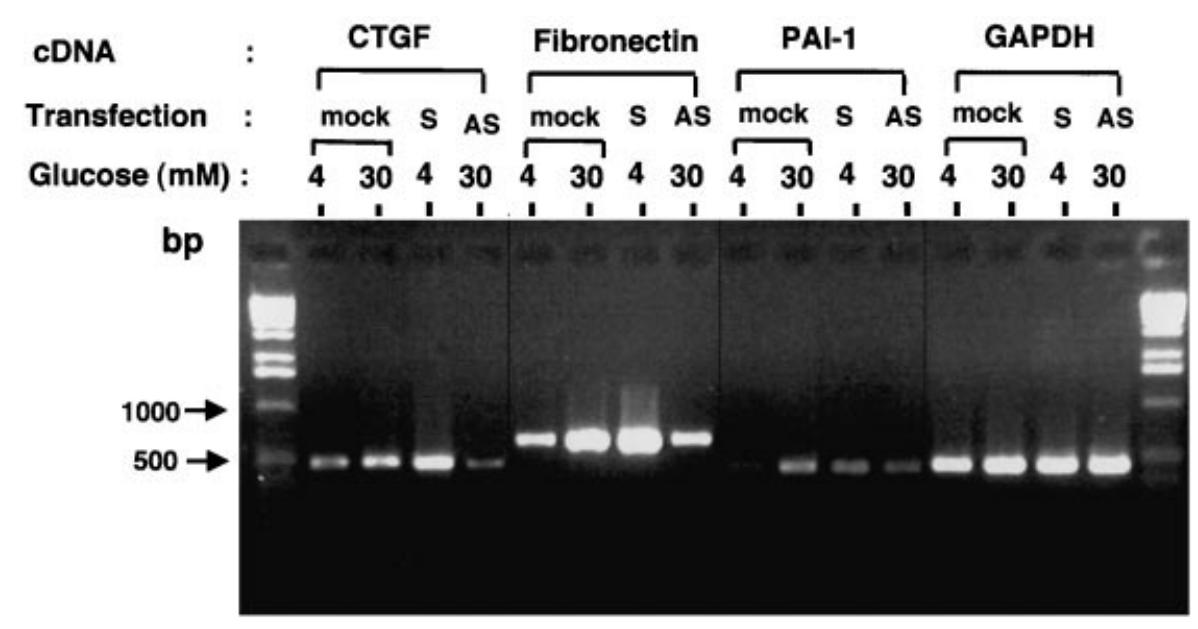

Figure 5 RT-PCR amplification of CTGF, fibronectin, PAI-1 and GAPDH transcripts in transiently transfected THMC cultures

mRNA was extracted from mock-transfected THMCs (mock) maintained under $4 \mathrm{mM}$ and $30 \mathrm{mM}$ D-glucose conditions, or from cells transfected with the CTGF-V5 construct (S) and maintained under 4mM D-glucose conditions, or with the CTGF-antisense construct (AS) and maintained under $30 \mathrm{mM}$ glucose conditions. RT-PCR was performed as described in the Materials and methods section using the primers listed in Table 1. 
Table 3 Quantitative assessment of mRNA levels of CTGF, fibronectin, PAI-1 and GAPDH in THMCs transfected with the CTGF-V5 construct or with the antisense (AS) construct

Following RT-PCR, as shown in Figure 5, cDNA bands for CTGF, fibronectin, PAI-1 and GAPDH were quantified with a scanning densitometer. The results shown are the integrated absorbance of each band in arbitrary units and are the means \pm S.E.M. for four separate RT-PCR analyses. Results of statistical analysis are given in the text. Three other experiments gave very similar results.

Integrated absorbance of cDNA band (arbitrary units)

CTGF Fibronectin PAL-1

\begin{tabular}{|c|c|c|c|c|c|c|c|c|c|}
\hline \multirow[b]{2}{*}{ Construct } & \multirow[b]{2}{*}{ [D-glucose] $(\mathrm{mM}) \ldots$} & & & & \\
\hline & & 4 & 30 & 4 & 30 & 4 & 30 & 4 & 30 \\
\hline Mock & & $3141 \pm 95$ & $6552 \pm 258$ & $10204 \pm 288$ & $26298 \pm 310$ & $1068 \pm 30$ & $4231 \pm 154$ & $12636 \pm 293$ & $12805 \pm 129$ \\
\hline CTGF-V5 & & $12472 \pm 205$ & - & $46566 \pm 791$ & - & $3227 \pm 236$ & - & $13028 \pm 178$ & - \\
\hline CTGF-AS & & - & $1475 \pm 100$ & - & $9190 \pm 401$ & - & $2484 \pm 218$ & - & $12889 \pm 416$ \\
\hline
\end{tabular}

mock-transfected THMC compared with $4 \mathrm{mM}$ D-glucose conditions (Figures 4A-4C, mock/4). Thus mock-transfected THMCs respond to high glucose with respect to fibronectin and PAI-1 expression in the same way as primary cultures of normal HMCs [27]. Over-expression of the CTGF gene under $4 \mathrm{mM}$ Dglucose conditions (Figure 4A, S/4) markedly increased the expression level of both fibronectin and PAI-1 proteins (Figures $4 \mathrm{~B}$ and $4 \mathrm{C}, \mathrm{S} / 4)$. The effect of over-expressing CTGF was more pronounced on secreted fibronectin levels than on secreted PAI-1 levels. Furthermore, depleting CTGF expression with an antisense construct in cells grown under high glucose conditions (Figure 4A, AS/30) prevented the increased expression of both fibronectin (Figure 4B, AS/30) and PAI-1 (Figure 4C, $\mathrm{AS} / 30$ ) when compared with the levels observed in lane mock $/ 30$ (Figures 4B and 4C). Thus both fibronectin and PAI-1 protein levels are upregulated directly by endogenously expressed rCTGF in the $4 \mathrm{mM}$ D-glucose cultures and by endogenous native CTGF in high glucose conditions.

RT-PCR analysis confirmed that increased CTGF expression occurs in THMCs in high glucose $(P<0.0001)$, or in low glucose after transfection with the CTGF-sense construct $(P<0.0001)$ compared with mock-transfected cells in low glucose (Figure 5 and Table 3). Endogenous CTGF transcripts in high glucose were greatly reduced in cells transfected with the antisense vector $(P<0.001)$ compared with mock-transfected cells in these conditions. Moreover, the level of gene expression for fibronectin and PAI-1 correlated closely with the level of CTGF expression, in each condition $(P<0.0001$ for fibronectin and $P<0.001$ for PAI-1). Collectively these results indicate that changes in fibronectin and PAI-1 protein levels in high glucose are due to increased mRNA levels, which are to a significant extent controlled by CTGF.

\section{Role of CTGF in elevated fibronectin synthesis in HMCs exposed long term to high glucose or $\operatorname{TGF} \beta 1$}

Exposure of mesangial cells to high glucose conditions over 14-21 days to simulate chronic hyperglycaemia in vivo induces a sustained increase in TGF $\beta 1$ synthesis and bioactivity [34,35], and up-regulated expression of this factor is implicated in the development of glomerulosclerosis in DN [36,37]. It has been proposed that the CTGF acts downstream of TGF $\beta 1$ to mediate the latter's profibrotic effects $[18,19]$. To test directly whether increased CTGF expression is wholly responsible for the elevated synthesis of fibronectin in mesangial cells exposed chronically to high glucose $(30 \mathrm{mM})$ or to TGF $\beta 1(5 \mathrm{ng} / \mathrm{ml})$ in low glucose conditions $(4 \mathrm{mM})$, we co-treated human primary cultures over 14 days with either a CTGF-antisense oligonucleotide, or with
Table 4 Role of CTGF in mediating the stimulatory effect of high glucose conditions on fibronectin synthesis in primary HMCs

Primary cultures were maintained under the conditions shown for a period of 14 days. During the last $24 \mathrm{~h}$ of the experiment the cultures were maintained in serum-free conditions. Secreted fibronectin protein was measured in the conditioned serum-free media using ELISA, as described in the Materials and methods section. The results represent the mean \pm S.E.M. for three separate experiments with triplicate cultures for each condition in each experiment. Results of statistical analysis are given in the text. Abbreviations: Ab, antibody; AS, antisense.

\begin{tabular}{|c|c|c|c|}
\hline \multirow[b]{2}{*}{ Treatment } & \multirow[b]{2}{*}{ [D-glucose] (mM). } & \multicolumn{2}{|c|}{$\begin{array}{l}\text { Fibronectin synthesis } \\
\text { (ng/10 } 10^{4} \text { cells per } 24 \text { h) }\end{array}$} \\
\hline & & 4 & 30 \\
\hline None & & $9.9 \pm 1.6$ & $15.0 \pm 1.1$ \\
\hline TGF $\beta 1(5 \mathrm{ng} / \mathrm{ml})$ & & $12.0 \pm 0.9$ & - \\
\hline rCTGF (40 ng/ml) & & $15.0 \pm 1.5$ & - \\
\hline CTGF-AS oligo $(1.6 \mu \mathrm{M})$ & & - & $12.0 \pm 0.5$ \\
\hline Control-AS oligo (1.6 $\mu \mathrm{M})$ & & - & $14.3 \pm 0.5$ \\
\hline Anti-CTGF Ab $(0.4 \mu \mathrm{g} / \mathrm{ml})$ & & - & $12.8 \pm 0.7$ \\
\hline Pre-immune serum $(0.4 \mu \mathrm{g} / \mathrm{ml})$ & & - & $14.5 \pm 0.9$ \\
\hline TGF $\beta 1$ plus CTGF AS oligo & & $7.9 \pm 0.9$ & - \\
\hline TGF $\beta 1$ plus control AS oligo & & $12.2 \pm 0.9$ & - \\
\hline TGF $\beta 1$ plus anti-CTGF Ab & & $8.2 \pm 0.5$ & - \\
\hline TGF $\beta 1$ plus pre-immune serum & & $12.0 \pm 0.5$ & - \\
\hline
\end{tabular}

a chick anti-CTGF neutralizing antibody (pIgY3). Control cultures were treated with either a control oligonucleotide (see the Materials and methods section) or with chick pre-immune serum. All cultures were maintained in media supplemented with $10 \%$ FCS for 14 days, after which they were washed with PBS and exposed to the same conditions, but in the absence of FCS, for the final $24 \mathrm{~h}$. Fibronectin was measured in the conditioned media by ELISA, and RNA was extracted from the cells and used to evaluate the steady state mRNA levels of CTGF and fibronectin by RT-PCR. Some cultures were also treated with rCTGF (40 ng/ml; FibroGen).

High glucose conditions increased the level of secreted fibronectin by approx. $50 \%(P<0.002)$ compared with that in low glucose conditions, as expected [27] (Table 4). rCTGF added to low glucose cultures also stimulated fibronectin synthesis by $50 \%(P<0.004$, Table 4$)$, a level similar to that observed when serum-starved rat mesangial cells were treated for $48 \mathrm{~h}$ with $20 \mathrm{ng} / \mathrm{ml}$ of the same rCTGF [15]. In comparison, TGF $\beta 1$ only induced a $20 \%$ increase in secreted fibronectin in low glucose cultures $(P<0.05$, Table 4$)$. However, high glucose, and rCTGF 
Table 5 Quantitative assessment of the role of CTGF in mediating stimulation of mRNA levels of fibronectin in normal human mesangial cells

Following RT-PCR, as shown in Figure 6, CDNA bands for CTGF, fibronectin and GAPDH were quantified with a scanning densitometer. The results shown are the integrated absorbance of each band in arbitrary units and are the means \pm S.E.M. for four separate RT-PCR analyses. Results of statistical analysis are given in the text. Three other experiments gave very similar results. Abbreviations: Ab, antibody; AS, antisense; oligo, oligonucleotide.

\begin{tabular}{|c|c|c|c|c|c|c|c|}
\hline \multirow[b]{3}{*}{ Treatment } & \multirow[b]{3}{*}{ [o-glucose] $(\mathrm{mM}) \ldots$} & \multicolumn{6}{|c|}{ Integrated absorbance of cDNA band (arbitrary units) } \\
\hline & & \multicolumn{2}{|l|}{ CTGF } & \multicolumn{2}{|l|}{ Fibronectin } & \multicolumn{2}{|l|}{ GAPDH } \\
\hline & & 4 & 30 & 4 & 30 & 4 & 30 \\
\hline None & & $2179 \pm 161$ & $12168 \pm 500$ & $8498 \pm 349$ & $16892 \pm 576$ & $12608 \pm 642$ & $13320 \pm 431$ \\
\hline TGF $\beta 1$ & & $10697 \pm 542$ & - & $15704 \pm 278$ & - & $13320 \pm 431$ & - \\
\hline ICTGF & & $12185 \pm 211$ & - & $16954 \pm 105$ & - & $12946 \pm 608$ & - \\
\hline CTGF-AS oligo & & - & $1072 \pm 85$ & - & $13674 \pm 462$ & - & $13123 \pm 349$ \\
\hline Control-AS oligo & & - & $12003 \pm 657$ & - & $16060 \pm 96$ & - & $12903 \pm 209$ \\
\hline Anti-CTGF Ab & & - & $8254 \pm 503$ & - & $13853 \pm 96$ & - & $12903 \pm 209$ \\
\hline Pre-immune serum & & - & $12281 \pm 210$ & - & $16874 \pm 250$ & - & $12697 \pm 514$ \\
\hline TGF $\beta 1$ plus CTGF-AS oligo & & $1202 \pm 85$ & - & $12168 \pm 611$ & - & $13034 \pm 265$ & - \\
\hline TGF $\beta 1$ plus control-AS oligo & & $12222 \pm 801$ & - & $16622 \pm 331$ & - & $12762 \pm 607$ & - \\
\hline TGF $\beta 1$ plus anti-CTGF Ab & & $12074 \pm 631$ & - & $13253 \pm 291$ & - & $12330 \pm 490$ & - \\
\hline TGF $\beta 1$ plus pre-immune serum & & $12188 \pm 518$ & - & $16030 \pm 247$ & - & $12749 \pm 510$ & - \\
\hline
\end{tabular}

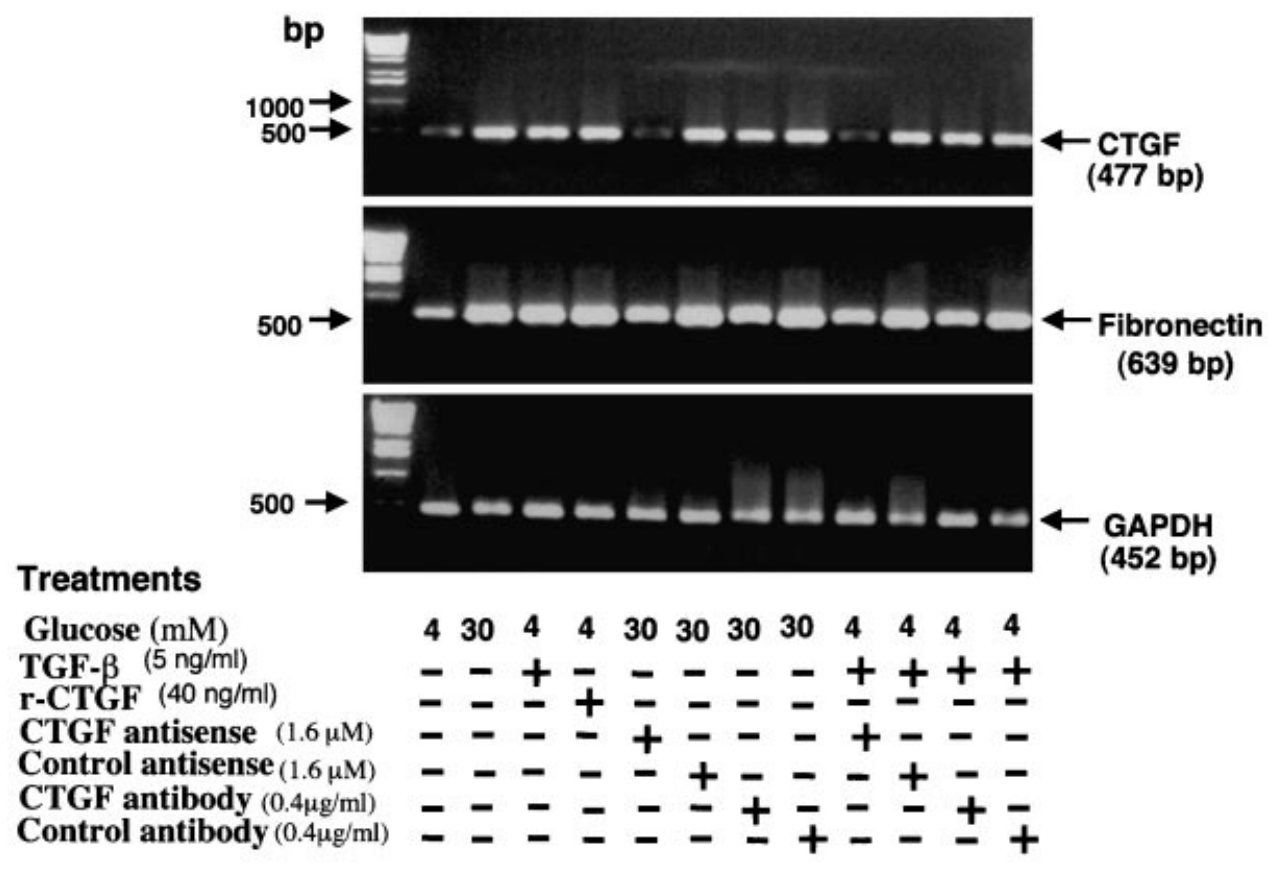

Figure 6 RT-PCR amplification of CTGF, fibronectin and GAPDH transcripts in normal HMCs

RNA was extracted from primary mesangial cells maintained under the following conditions for 14 days: $4 \mathrm{mM}$ D-glucose, $30 \mathrm{mM} \mathrm{D}$-glucose, $4 \mathrm{mM}$ D-glucose plus TGF $\beta 1$ (5 ng/ml), $4 \mathrm{mM}$ $\mathrm{D}$-glucose plus rCTGF ( $40 \mathrm{ng} / \mathrm{ml}), 30 \mathrm{mM} \mathrm{D}$-glucose plus CTGF antisense or control antisense oligonucleotide $(1.6 \mu \mathrm{M}), 30 \mathrm{mM}$ D-glucose plus CTGF neutralizing antibody $(0.4 \mu \mathrm{g} / \mathrm{ml})$ or pre-immune serum $(0.4 \mu \mathrm{g} / \mathrm{ml}), 4 \mathrm{mM}$ D-glucose and TGF $\beta 1(5 \mathrm{ng} / \mathrm{ml})$ plus CTGF antisense or control antisense oligonucleotide $(1.6 \mu \mathrm{M}), 4 \mathrm{mM}$ D-glucose and TGF $\beta 1$ (5 ng/ml) plus CTGF neutralizing antibody or CTGF pre-immune serum $(0.4 \mu \mathrm{g} / \mathrm{ml})$. RT-PCR was performed as described in the Materials and methods section using the primers listed in Table 1.

and TGF $\beta 1$ supplements to low glucose conditions, all induced similar levels of CTGF and fibronectin mRNAs compared to low glucose alone (Figure 6 and Table $5 ; P<0.0001$ for all).

When high glucose cultures were treated continuously with CTGF-antisense oligonucleotide, CTGF mRNA levels fell to only $50 \%$ of those recorded in low glucose cultures (Figure 6 and Table $5 ; P<0.0001)$ and to less than $10 \%$ of those in high glucose control cultures. However, the fibronectin mRNA pool in high glucose cultures was only reduced by approx. $20 \%$ in the presence of the CTGF-antisense oligonucleotide (Table 5; $P<$ 0.0001 ) and secreted fibronectin levels were still approx. $25 \%$ higher than in $4.0 \mathrm{mM}$ glucose-maintained cultures (Table 4; $P<0.003$ ). Thus increased CTGF expression does not appear to be the only factor driving increased fibronectin expression in primary cultures of HMCs exposed long term to high glucose conditions. The control oligonucleotide had negligible effects on the CTGF or fibronectin mRNA pool sizes, or on the level of secreted fibronectin. 
Interestingly, the chick anti-CTGF antibody brought about a partial reduction in the CTGF mRNA pool size in high glucose cultures (approx. 32\%), although it remained increased by 4 -fold over that in low glucose conditions (Table 5). This result suggests that at least some newly synthesized CTGF must be exported from the cells and act in an autocrine manner on the cells to stimulate further CTGF transcription. Treatment with the antiCTGF antibody also appeared to reduce the fibronectin mRNA pool size by about $20 \%$ in high glucose cultures (Table 5 , but difference not significant in Student's $t$-test), and reduced stimulation of secreted fibronectin protein levels by $44 \%$ in such cultures (Table $4 ; P<0.02$ ). Thus only part of the elevation in fibronectin synthesis in high glucose conditions can be attributed to increased CTGF leaving the cell and acting via an autocrine manner to induce new fibronectin gene expression and protein synthesis.

Treating TGF $\beta 1$-stimulated cultures with antisense-CTGF oligonucleotide not only abolished any increase in the CTGF transcript pool, but reduced it to less than that found in cells maintained in $4.0 \mathrm{mM}$ D-glucose alone (Figure 6 and Table 5; $P<0.0001)$. This effect was similar to the effect of the antisense oligonucleotide on the high glucose cultures (Table 5). In contrast, treating TGF $\beta 1$-stimulated $4.0 \mathrm{mM}$ cultures with anti-CTGF antibody had no effect on the CTGF mRNA pool size whereas, as described above, such treatment reduced it partially in high glucose-treated cells (Table 5). Since controls (oligonucleotide or pre-immune serum) had no effect in either situation, this suggests that high glucose induces factors in addition to TGF $\beta 1$ which modulate the CTGF mRNA pool size.

Both the antisense-CTGF oligonucleotide and the anti-CTGF antibody completely abolished the stimulatory effect of TGF $\beta 1$ on secreted fibronectin protein levels (Table 4; $P<0.0004$ and $P<0.0001$ respectively), even though they only partially reduced the stimulatory effect of the growth factor on the fibronectin mRNA pool sizes (Figure 6 and Table 5; $P<0.0001$ for oligonucleotide and $P<0.03$ for antibody). The result of the CTGF-antisense treatment shows that the fibronectin mRNA pool size is not wholly dependent on elevated CTGF expression in TGF $\beta 1$-stimulated cultures, although clearly fibronectin protein synthesis is dependent. CTGF may also induce expression of a factor which is required to achieve increased fibronectin synthesis.

Overall these results support a hypothesis in which high levels of glucose stimulate the expression of CTGF. The latter acts downstream to amplify its own expression in an autocrine loop, but is only partially responsible for inducing up-regulation of fibronectin expression in these conditions. Interestingly, although CTGF-antisense and anti-CTGF antibodies have a similar effect on the fibronectin mRNA pool size in cultures in high glucose, or in low glucose conditions supplemented with TGF $\beta 1$, both strategies have a more pronounced effect relatively in reducing fibronectin protein levels in the culture medium of TGF $\beta 1$ treated cells than they do with the high glucose-treated cells (Table 4).

\section{DISCUSSION}

In the present study we aimed to assess whether CTGF is upregulated at the protein level in the diabetic glomerulus in vivo, and whether the factor is solely responsible for the increased synthesis of the matrix protein, fibronectin, in mesangial cells exposed long term to high glucose or elevated TGF $\beta 1$ levels in vitro. To investigate the former, we had first to biochemically characterize a polyclonal antibody for immunochemical detection of CTGF in tissues. To directly test the role of CTGF gene expression in the response of mesangial cells to high glucose and TGF $\beta 1$ levels, we adopted an antisense strategy to successfully knock out CTGF mRNA in these conditions. We also compared the effects of the antisense strategy with those of treating cells with a chick anti-CTGF neutralizing antibody. These complementary approaches have provided new information about CTGF, showing that: (1) it is present in mesangial cell cultures in a high molecular mass form, in addition to the monomeric form and as low molecular mass peptides derived from it; (2) increased levels of CTGF protein are present in murine and human diabetic glomeruli; (3) whereas increased expression of CTGF alone is sufficient to up-regulate fibronectin production, it can only partially account for the elevated level of synthesis of the matrix protein during long-term exposure of mesangial cells to high glucose; (4) increased expression of CTGF stimulates increased expression and synthesis of PAI-1.

After expressing a rCTGF-V5-fusion protein in THMCs, monomers and bands of higher and lower molecular mass were present in cell cultures. The same bands were detected by both the anti-V5 antibody and the rabbit anti-rCTGF antibody from FibroGen, and binding was eliminated by pre-absorption of the latter by rCTGF. The lower molecular mass bands are likely to be cleavage products of CTGF containing modules IV, or III and IV from the C-terminal end of the protein, as reported previously for other systems [6,7]. We speculate that the higher molecular mass band $(56 \mathrm{kDa})$ could be a complex formed between CTGF and one of its smaller cleavage products or another protein. A similar high molecular mass band was present in cell lysates of mock-transfected THMCs and of primary HMC cultures, so it is formed physiologically in vitro and is not an artefact due to the CTGF-fusion protein.

This study is the first to demonstrate that increased levels of CTGF protein are present in the glomerulus in both murine and human diabetes. Hardly any CTGF immunostaining was present in the glomeruli of either normal human or control NOD mouse kidney, although Ito et al. [23] detected CTGF mRNA in visceral and some parietal epithelial cells. The amount of CTGF immunostaining correlated with the duration of diabetes in NOD mice and was prominent 70 days after the onset of diabetes. This may reflect the increase in TGF $\beta 1$ expression that occurs after a short period of hyperglycaemia (3-7 days) in this diabetic mouse model [36]. Thus it is clear that glomerular CTGF expression is upregulated at the protein level in diabetes, as well as at the mRNA level, as reported by Ito et al. [23] and others $[4,15]$. This is an important finding since increases in CTGF-transcript level are not always accompanied by increased amounts of protein, as was found when rat mesangial cells were mechanically stretched [15].

Transient overexpression of CTGF in THMCs, or addition of rCTGF to primary HMCs, confirmed that CTGF is a strong inducer of fibronectin $[4,15]$ and showed that it is an inducer of PAI-1 in mesangial cells. The latter is a significant finding since we have shown previously [38] that increased expression of PAI1 occurs in primary mesangial cells exposed to long-term high glucose conditions, and that it is accompanied by loss of tissue-plasminogen activator activity. Since tissue plasminogen activator is an important activator for the matrix metalloproteinases which are responsible for matrix turnover, upregulation of PAI-1 by CTGF is likely to contribute significantly to mesangial matrix accumulation and glomerulosclerosis in the diabetic glomerulus.

As described in rat mesangial cells [15], rCTGF induced endogenous CTGF expression in HMCs, suggesting an autocrine amplification loop in this cell type. Also, as expected, TGF $\beta 1$ stimulated expression of CTGF mRNA and synthesis of fibro- 
nectin in HMCs maintained in low glucose conditions. However, although long-term exposure to high glucose increases levels of TGF $\beta 1$ mRNA, protein and bioactivity $[34,35]$ and stimulated an increase in the CTGF mRNA pool size, CTGF alone does not account fully for the increase in fibronectin synthesis in these conditions. CTGF mRNA levels were almost eliminated in highglucose cultures by treatment with the CTGF-antisense oligonucleotide, but fibronectin mRNA and protein levels were only partially reduced. Similarly interrupting the putative autocrine action of CTGF with a neutralizing antibody only partially reduced fibronectin synthesis in high glucose conditions. This indicates that signalling pathways in addition to the TGF $\beta 1-C T G F$ pathway are involved in upregulating mesangial cell fibronectin expression in primary mesangial cells exposed to long-term high-glucose conditions.

TGF $\beta 1$ is secreted as an inactive form in a complex with the latency-associated peptide. We have shown that TGF $\beta 1$ activation in high glucose conditiond depends entirely on interaction of its latent complex with thrombospondin-1 [35], a known activator of the complex [39]. Blocking the thrombospondin-1/TGF $\beta 1$-activation mechanism in high glucose mesangial cell cultures prevented any increases in fibronectin mRNA or protein [35], inferring that upregulated expression of fibronectin is totally dependent on TGF $\beta 1$ in such conditions. Thus if signalling pathways other than the TGF $\beta 1-\mathrm{CTGF}$ pathway are involved in upregulation of fibronectin in high glucose, they must nevertheless involve TGF $\beta 1$. It seems possible that if one pathway mediating the effects of TGF $\beta 1$ is markedly inhibited, for example the CTGF pathway by the antisense oligonucleotide treatment, an alternative pathway may partially compensate for this.

Activation of TGF $\beta 1$-responsive genes appears to be mediated by several different pathways. Thus, TGF $\beta 1$-stimulated synthesis of PAI-1 can be mediated via the Smad-signalling cascade [40-42], but stimulation of fibronectin synthesis in a human fibrosarcoma-derived cell line occurs independently of Smad4 [43]. TGF $\beta 1$ stimulated fibronectin through the c-Jun N-terminal kinase pathway in these cells. Interestingly, high glucose conditions and TGF $\beta 1$ stimulated fibronectin gene expression in HMCs through a cAMP-response element (CRE) in its promoter $[44,45]$. Induction of fibronectin transcription in HMC is due primarily to the phosphorylation of CRE-binding protein, which binds to this element [45]. In mesangial cells TGF $\beta 1$ stimulates protein kinase A activation via the phosphorylation and degradation of inhibitory molecules that interact with the catalytic subunit of protein kinase A [45]. Overexpressing the inhibitory molecules in mesangial cells attenuates TGF $\beta 1$-induced stimulation of fibronectin mRNA expression. Moreover addition of $\mathrm{H}-89$, the protein kinase A specific inhibitor, does not affect Smad-2 phosphorylation, but completely inhibits TGF $\beta 1$ induced cAMP-response-element-binding protein phosphorylation in mesangial cells and hence inhibits TGF $\beta 1$-induced stimulation of fibronectin gene expression [46].

It should be noted that TGF $\beta 1$-independent pathways augment TGF $\beta 1$-dependent ones by stimulating increased expression of some matrix proteins in high glucose conditions. Thus upregulated expression of decorin in such conditions is driven predominantly from a CRE-like response element in the P1 promoter of the gene [28]. Although this element is responsive to TGF $\beta 1$, neutralizing anti-TGF $\beta 1$ antibodies were only able to partly suppress increased decorin transcription when P1-promoter activity was stimulated by high glucose, inferring the presence of TGF $\beta 1$-independent signals in these conditions. In contrast, increased fibronectin expression in mesangial cells exposed to high glucose was completely suppressed by either
TGF $\beta 1$-neutralizing antibodies [34] or by inhibiting activation of TGF $\beta 1$ in high glucose [35].

In summary, our results strongly support a role for CTGF in the pathogenesis of DN. Antagonism of CTGF function could possibly attenuate, but not completely block, progression of the glomerulosclerosis in this disease. Such an approach may, however, avoid the possible pro-carcinogenic danger associated with the blockade of TGF $\beta 1$ [47], which has been proposed as another therapeutic strategy for DN [48].

We thank the Medical Research Council (U.K.) and Diabetes U.K. for financial support, and Dr. Masakazu Hattori and Professor Anne Cooke for NOD mouse and control mouse kidneys. N.Y. is grateful to the Wellcome Trust for a Travelling Research Fellowship and X.J.L. acknowledges support from an Overseas Research Studentship Award and the Special Trustees of Charing Cross Hospital.

\section{REFERENCES}

1 The Diabetic Control and Complications Trial Research Group. (1993) The effect of intensive treatment of diabetes on the development and progression of long-term complication in insulin-dependent diabetes mellitus. N. Engl. J. Med. 329, 977-986

2 Gilbert, R. E. and Cooper, M. E. (1999) The tubulointerstitium in progressive diabetic kidney disease: more than an aftermath of glomerular injury? Kidney Int. 56, 1627-1637

3 Mason, R. M., Li, X. J. and Wahab, N. A. (1997) High glucose induces the expression of connective tissue growth factor in human mesangial cells. J. Am. Soc. Nephrol. 8, 642A

4 Murphy, M., Godson, C., Cannon, S., Kato, S., Mackenzie, H. S., Martin, F. and Brady, H. R. (1999) Suppression subtractive hybridization identifies high glucose level as a stimulus for expression of connective tissue growth factor and other genes in human mesangial cells. J. Biol. Chem. 274, 5830-5834

5 Lau, L. F. and Lam, SC. (1999) The CCN family of angiogenic regulators: the integrin connection. Exp. Cell Res. 248, 44-57

6 Steffen, C. L., Ball-Marth, D. K., Harding, P. A., Bhattacharyya, N., Pillai, S. and Brigstock, D. R. (1998) Characterization of cell-associated and soluble forms of connective tissue growth factor (CTGF) produced by fibroblasts in vitro. Growth Factors 15, 199-213

7 Yang, D.-H., Kim, H.-S., Wilson, E. M., Rosenfeld, R. G. and Oh, Y. (1998) Identification of glycosylated 38-kDa connective tissue growth factor (IGFBP-related protein 2) and proteolytic fragments in human biological fluids, and up-regulation of IGFBP-rP2 expression by TGF- $\beta$ in Hs578T human breast cancer cells. J. Clin. Endocrinol. Metab. 83, 2593-2596

8 Ryseck, R.-P., Macdonald-Bravo, H., Mattei, M.-G. and Bravo, R. (1991) Structure, mapping, and expression of fisp-12, a growth factor-inducible gene encoding a secreted cysteine-rich protein. Cell Growth Differ. 2, 225-233

9 Brunner, A., Chinn, J., Neubauer, M. and Purchio, A. F. (1991) Identification of a gene family regulated by transforming growth factor- $\beta$. DNA Cell Biol. 10, 293-300

10 Igarashi, A., Okochi, H., Bradham, D. M. and Grotendorst, G. R. (1993) Regulation of connective tissue growth factor gene expression in human skin fibroblasts and during wound repair. Mol. Biol. Cell 4, 637-645

11 Nakanishi, T., Kimura, Y., Tamura, T., Ichikawa, H., Yamaai, Y.-I., Sugimoto, T. and Takigawa, M. (1997) Cloning of a mRNA preferentially expressed in chondrocytes by differential display-PCR from a human chondrocytic cell line that is identical with connective tissue growth factor (CTGF) mRNA. Biochem. Biophys. Res. Commun. 234, 206-210

12 Dammeier, J., Beer, H.-D., Brauchle, M. and Werner, S. (1998) Dexamethasone is a novel potent inducer of connective tissue growth factor expression. J. Biol. Chem. 273, 18185-18190

13 Chambers, R. C., Leoni, P., Blanc-Brude, Q. P., Wembridge, D. E. and Laurent, G. J. (2000) Thrombin is a potent inducer of connective tissue growth factor production via proteolytic activation of protease-activated receptor-1. J. Biol. Chem. 275, 35584-35591

14 Hahn, A., Heusinger-Ribeiro, J., Lanz, T., Zenkel, S. and Goppelt-Struebe, M. (2000) Induction of connective tissue growth factor by activation of heptahelical receptors. Modulation by Rho proteins and the actin cytoskeleton. J. Biol. Chem. 275, 37429-37435

15 Riser, B. L., Denichilo, M., Cortes, P., Baker, C., Grondin, J. M., Yee, J. and Natrins R. G. (2000) Regulation of connective tissue growth factor activity in cultured rat mesangial cells and its expression in experimental diabetic glomerulosclerosis. J. Am. Soc. Nephrol. 11, 25-38

16 Grotendorst, G. R., Okochi, H. and Hayashi, N. (1996) A novel transforming growth factor- $\beta$ response element controls the expression of the connective tissue growth factor gene. Cell Growth Differ. 7, 469-480 
17 Kubota, S., Hattori, T., Nakanishi, T. and Takigawa, M. (1999) Involvement of cisacting responsive element(s) in the $3^{\prime}$-untranslated region of human connective tissue growth factor gene. FEBS Lett. 450, 84-88

18 Kothapalli, D., Frazier, K. S., Welply, A., Segarini, P. R. and Grotendorst, G. R. (1997) Transforming growth factor $\beta$ induces anchorage-independent growth of NRK fibroblasts via a connective tissue growth factor-dependent signaling pathway. Cell Growth Differ. 8, 61-68

19 Grotendorst, G. R. (1997) Connective growth factor: a mediator of TGF- $\beta$ action on fibroblasts. Cytokine Growth Factor Rev. 8, 171-179

20 Dammeier, J., Brauchle, M., Falk, W., Grotendorst, G. R. and Werner, S. (1998) Connective tissue growth factor: a novel regulator of mucosal repair and fibrosis in inflammatory bowel disease. Int. J. Biochem. Cell Biol. 30, 909-922

21 Igarashi, A., Nashiro, K., Kikuchi, K., Sato, S., Ihn, H., Grotendorst, G. R. and Takehara, K. (1995) Significant correlation between connective tissue growth factor gene expression and skin sclerosis in tissue sections from patients with systemic sclerosis. J. Invest. Dermatol. 105, 280-284

22 Shi-Wen, X., Pennington, D., Holmes, A., Leask, A., Bradham, D., Beauchamp, R. J., Fonsecan, C., Du Bois, R. M., Martin, G. R., Black, C. M. and Abraham, D. J. (2000) Autocrine overexpression of CTGF maintains fibrosis: RDA analysis of fibrosis genes in systemic sclerosis. Exp. Cell Res. 259, 213-224

23 Ito, Y., Aten, J., Bende, R. J., Oema, B. S., Rabelink, T. J., Weening, J. J. and Goldschmeding, R. (1998) Expression of connective tissue growth factor in human renal fibrosis. Kidney Int. 53, 853-861

24 Gupta, S., Clarkson, M. R., Duggan, J. and Brady, H. R. (2000) Connective tissue growth factor: potential role in glomerulosclerosis and tubulointerstitial fibrosis. Kidney Int. 58, 1389-1399

25 Paradis, V., Dargere, D., Vidaud, M., De Gouville, A.-C., Huet, S., Martinez, V., Gauthier, J.-M., Ba, N., Sobesky, R., Ratziu, V. and Bedossa, P. (1999) Expression of connective tissue growth factor in experimental rat and human liver fibrosis. Hepatology 30, 968-976

26 Allen, J. T., Knight, R. A., Bloor, C. A. and Spiteri, M. A. (1999) Enhanced Insulin-like growth factor binding protein-related protein 2 (connective tissue growth factor) expression in patients with idiopathic pulmonary fibrosis and pulmonary sarcoidosis. Am. J. Respir. Cell Mol. Biol. 21, 693-700

27 Abdel Wahab, N., Harper, K. and Mason, R. M. (1996) Expression of extracellular matrix molecules in human mesangial cells in response to prolonged hyperglycaemia. Biochem. J. 316, 985-992

28 Abdel Wahab, N., Parker, S., Sraer, J.-D. and Mason, R. M. (2000) The decorin high glucose response element and mechanism of its activation in human mesangial cells. J. Am. Soc. Nephrol. 11, 1607-1619

29 Sraer, D.-J., Delarue, F., Hagege, J., Feunteun, J., Pinet, F., Nguyen, G. and Rondeau, E. (1996) Stable cell lines of T-SV40 immortalized human glomerular mesangial cells. Kidney Int. 49, 267-270

30 Hattori, M., Yamato, E., Itoh, N., Senpuku, H., Fujisawa, T., Yoshino, M., Fukuda, M., Matsumoto, E., Toyonaga, T., Nakaagawa, I. et al. (1999) Cutting edge: homologous recombination of the MHC class I K region defines new MHC-linked diabetogenic susceptibility gene(s) in nonobese diabetic mice. J. Immunol. 163, 1721-1724

31 Lund, T., O'Reilly, L., Hutchings, P., Kanagawa, O., Simpson, E., Gravely, R., Chandler, P., Dyson, J., Picard, J. K. and Edwards, A. (1990) Prevention of insulindependent diabetes mellitus in non-obese diabetic mice by transgenes encoding modified I-A $\beta$-chain or normal I-E $\alpha$-chain. Nature (London) 345, 727-729
32 Towbin, H., Staehelin, T. and Gordon, J. (1979) Electrophoretic transfer of proteins from polyacrylamide gels to nitrocellulose sheets: procedure and some applications. Proc. Natl. Acad. Sci. U.S.A. 75, 4350-4354

33 Doi, T., Hattori, M., Agodoa, L. Y. C., Sato, T., Yoshida, H., Striker, L. J. and Striker, G. E. (1990) Glomerular lesions in nonobese diabetic mouse: Before and after the onset of hyperglycemia. Lab. Invest. 63, 204-212

34 Oh, J. H., Ha, H., Yu, M. R. and Lee, H. B. (1998) Sequential effects of high glucose on mesangial cell transforming growth factor- $\beta 1$ and fibronectin synthesis. Kidney Int. 54, 1872-1878

35 Yevdokimova, N., Abdel Wahab, N. and Mason, R. M. (2001) Thrombospondin-1 is the key activator of TGF $\beta$ in human mesangial cells exposed to high glucose. J. Am. Soc. Nephrol. 12, 703-712

36 Sharma, K. and Ziyadeh, F. N. (1994) Renal hypertrophy is associated with upregulation of TGF- $\beta 1$ gene expression in diabetic BB rat and NOD mouse. Am. J. Physiol. 267, F1094-F1101

37 Iwano, M., Kubo, A., Nishino, T., Sato, H., Nishioka, H., Akai, Y., Kurioka, H., Fujii, Y., Kanauchi, M., Shiiki, H. and Dohl, K. (1996) Quantification of glomerular TGF- $\beta 1$ mRNA in patients with diabetes mellitus. Kidney Int. 49, 1120-1126

38 Abdel Wahab, N. and Mason, R. M. (1996) Modulation of neutral protease expression in human mesangial cells by hyperglycaemic culture. Biochem. J.. 320, 777-783

39 Murphy-Ullrich, J. E. and Poczatek, M. (2000) Activation of latent TGF- $\beta 1$ by thrombospondin-1: mechanisms and physiology. Cytokine Growth Factor Rev. 11, 59-69

40 Dennler, S., Itoh, S., Vivien, D., ten Dijke, P., Huet, S. and Gauthier, J. M. (1998) Direct binding of Smad3 and Smad4 to critical TGF- $\beta$-induced elements on the promoter of human plasminogen activator inhibitor-type 1 gene. EMBO J. 17, $3091-3100$

41 Stroschein, S. L., Wang, W. and Luo, K. (1999) Cooperative binding of Smad protein to two adjacent DNA elements in the plasminogen activator inhibitor-1 promoter mediates transforming growth factor $\beta$-induced smad-dependent transcription activation. J. Biol. Chem. 274, 9431-9341

42 Hua, X., Lui, X., Ansari, D. O. and Lodish, H. F. (1998) Synergistic cooperation of TFE3 and smad proteins in TGF- $\beta$-induced transcription of the plasminogen activator inhibitor-1 gene. Genes Dev. 12, 3084-3095

43 Hocevar, B., Brown, T. and Howe, P. (1999) TGFbeta induces fibronectin synthesis through a C-Jun N-terminal kinase-dependent, Smad4-independent pathway. EMBO J. 18, 1345-1356

44 Kreisberg, J. I., Garoni, J. N., Radnik, R.I. and Ayo, S. H. (1994) High glucose and TGF- $\beta 1$ stimulate fibronectin gene expression through a cAMP response element. Kidney Int. 46, 1019-1024

45 Kreisberg, J. I., Radnik, R. A. and Kreisberg, S. H. (1996) Phosphorylation of cAMP responsive element binding protein after treatment of mesangial cells with high glucose plus TGF $\beta$ or PMA. Kidney Int. 50, 805-810

46 Wang, L., Zhu, Y. and Sharma, K. (1998) Transforming growth factor- $\beta 1$ stimulates protein kinase A in mesangial cells. J. Biol. Chem. 273, 8522-8527

47 Brattain, M. G., Markovitz, S. D. and Wilson, J. K. V. S. (1996) Type II transforming growth factor- $\beta$ receptor as a tumor suppressor gene. Curr. Opin. Oncol. 8, 49-53

48 Sharma, K., Guo, J., Jin, Y. and Ziyadeh, F. N. (1996) Neutralization of TGF- $\beta$ by anti-TGF- $\beta$ antibody attenuates kidney hypertrophy and the enhanced extracellular matrix gene expression in STZ-induced diabetic mice. Diabetes 45, 522-530

Received 2 February 2001/15 May 2001; accepted 16 July 2001 